\title{
Herbivory of an invasive slug is affected by earthworms and the composition of plant communities
}

Johann G Zaller ${ }^{*}$, Myriam Parth', Ilona Szunyogh', Ines Semmelrock', Susanne Sochurek', Marcia Pinheiro ', Thomas Frank ${ }^{1}$ and Thomas Drapela ${ }^{1,2}$

\begin{abstract}
Background: Biodiversity loss and species invasions are among the most important human-induced global changes. Moreover, these two processes are interlinked as ecosystem invasibility is considered to increase with decreasing biodiversity. In temperate grasslands, earthworms serve as important ecosystem engineers making up the majority of soil faunal biomass. Herbivore behaviour has been shown to be affected by earthworms, however it is unclear whether these effects differ with the composition of plant communities. To test this we conducted a mesocosm experiment where we added earthworms (Annelida: Lumbricidae) to planted grassland communities with different plant species composition (3 vs. 12 plant spp.). Plant communities had equal plant densities and ratios of the functional groups grasses, non-leguminous forbs and legumes. Later, Arion vulgaris slugs (formerly known as A. lusitanicus; Gastropoda: Arionidae) were added and allowed to freely choose among the available plant species. This slug species is listed among the 100 worst alien species in Europe. We hypothesized that (i) the food choice of slugs would be altered by earthworms' specific effects on the growth and nutrient content of plant species, (ii) slug herbivory will be less affected by earthworms in plant communities containing more plant species than in those with fewer plant species because of a more readily utilization of plant resources making the impacts of earthworms less pronounced.

Results: Slug herbivory was significantly affected by both earthworms and plant species composition. Slugs damaged $60 \%$ less leaves when earthworms were present, regardless of the species composition of the plant communities. Percent leaf area consumed by slugs was $40 \%$ lower in communities containing 12 plant species; in communities containing only three species earthworms increased slug leaf area consumption. Grasses were generally avoided by slugs. Leaf length and number of tillers was increased in mesocosms containing more plant species but little influenced by earthworms. Overall shoot biomass was decreased, root biomass increased in plant communities with more plant species. Earthworms decreased total shoot biomass in mesocosms with more plant species but did not affect biomass production of individual functional groups. Plant nitrogen concentrations across three focus species were 18\% higher when earthworms were present; composition of plant communities did not affect plant quality.
\end{abstract}

Conclusions: Given the important role that both herbivores and earthworms play in structuring plant communities the implications of belowground-aboveground linkages should more broadly be considered when investigating global change effects on ecosystems.

Keywords: Belowground-aboveground interactions, Ecosystem functioning, Biodiversity loss, Plant-animal interactions, Soil invertebrates, Invasive herbivores, Plant community composition, Global change ecology

\footnotetext{
* Correspondence: johann.zaller@boku.ac.at

'Institute of Zoology, Department of Integrative Biology and Biodiversity Research, University of Natural Resources and Life Sciences Vienna, Gregor Mendel Straße 33, A-1180, Vienna, Austria

Full list of author information is available at the end of the article
}

\section{Biomed Central}

(c) 2013 Zaller et al.; licensee BioMed Central Ltd. This is an Open Access article distributed under the terms of the Creative Commons Attribution License (http://creativecommons.org/licenses/by/2.0), which permits unrestricted use, distribution, and reproduction in any medium, provided the original work is properly cited. 


\section{Background}

The loss of biodiversity and the invasion by non-native species are among the most important human-induced global change factors [1]. Both processes have generated concern regarding their consequences for ecosystem functioning and understanding the relationship between both has become a major focus in modern ecological research [2-4]. The biodiversity-invasibility hypothesis [5,6] states, that high diversity increases the competitive environment of communities making them harder to invade. Numerous biodiversity experiments have been conducted aiming to test this hypothesis [7-9]. Underlying mechanisms comprise a decreased chance of empty ecological niches, an increased probability of competitors that preclude invasion success, a more complete resource use in diverse communities and limited ability of invaders to establish $[4,6,10,11]$. Most studies focus on the invasibility of plant communities for invasive plant species [12], however very little is known on the invasibility of plant communities for invasive herbivores. To the best of our knowledge, nothing is known about the role of soil fauna in affecting invasive herbivores in plant communities with different plant species composition.

Earthworms often make up the majority of soil faunal biomass in grasslands, comprise the dominant group of the decomposer community, stimulating the microbial activity and the availability of nutrients in soil [13-15]. In temperate grasslands, these earthworm communities commonly consist of a few species [16] comprising three functional groups: surface dwelling epigeics, vertically burrowing anecics and horizontally burrowing endogeics [17]. The loss of plant species diversity in grasslands has been shown to affect abundance, biomass and activity of earthworms [18-21]. On the other hand, effects of earthworms have been shown to benefit certain plant functional groups more than others [22-25] affecting plant community structure and diversity [26]. The role of earthworms has been most often studied on a single plant species, while only few have investigated effects on plant communities [27-31].

Gastropods (slugs and snails) influence the species composition and relative abundance of plant communities by selectively grazing certain plant species [32-38]. Slug grazing has been shown to shift plant competition in mixed swards and influencing the uptake and partitioning of nutrients among plants [39]. Across Europe, the slug Arion vulgaris Moquin-Tandon, formerly known as $A$. lusitanicus is an up to $15 \mathrm{~cm}$ long, polyphagous slug species, natively distributed in northern Spain, western France and southern England. This slug is highly invasive all over Europe during the last 30 years and listed among the 100 worst alien species in Europe (http://www.europealiens.org/); since 1998 it is also becoming established in the USA [40]. Earthworms have been shown to affect sap-sucking and chewing herbivores such as snails and slugs $[33,41]$ in different ways via changes in leaf chemistry see literature reviewed by [42].

The aim of this study was to test whether (i) slug herbivory in plant communities is affected by earthworms and (ii) whether potential influences of earthworms are altered by the composition of plant communities. We hypothesized that (i) the food choice of slugs would be altered by earthworms' specific effects on the growth and nutrient content of plant species, (ii) slug herbivory will be less affected by earthworms in plant communities containing more plant species because of a more readily utilization of resources by plants making the impacts of earthworms less pronounced. Slug herbivory on focus species could additionally be affected by potential differences in available plant biomass or microclimate between plant communities differing plant species numbers. These hypotheses were tested in a full-factorial greenhouse experiment using 20-1 mesocosms manipulating both earthworms and plant species composition.

\section{Methods}

\section{Experimental setup}

We set up a full-factorial experiment using 20-1 mesocosms (diameter $31 \mathrm{~cm}$, height $34 \mathrm{~cm}$ ) in an unheated greenhouse of the University of Natural Resources and Life Sciences (BOKU), Vienna, Austria. Treatment factors were earthworms ("-Ew" - no earthworms; "+Ew" - addition of two adult individuals of the vertical-burrowing anecic Lumbricus terrestris L. and four adult/sub-adult individuals of the soil dwelling endogeic $A$. caliginosa Savigny per mesocosm) and plant community composition ("low diversity" - 3 plant species, "high diversity" - 12 plant species; Table 1). These species are typically co-occurring in many Central European grasslands.

Planting of mesocosms followed a consistent hexagonal pattern with 60 positions in equidistance of $3.5 \mathrm{~cm}$ between plant individuals and the same positions of the functional groups (grasses, forbs and legumes) across all mesocosms. Sowing was done directly in the mescosms by placing two seeds per position; surplus seedlings were removed to achieve the desired planting pattern of 60 plants per mesocosm. The mesocosms were watered with tap water using the same amount for each mesocosm depending on the temperature conditions in the greenhouse. Before we added the earthworms the plants were fertilized once with $20 \mathrm{ml} \mathrm{pot}^{-1}$ of customary NPK $(7+3+6)$ fertilizer to foster seedling establishment.

Earthworms were added four weeks after sowing the plants (mean fresh mass \pm SE of $8.86 \pm 0.13 \mathrm{~g}$ mesocosms $^{-1}$ L. terrestris and $3.16 \pm 0.06$ g mesocosm $^{-1}$ for A. caliginosa); added total earthworm density or biomass translates to 333 individuals $\mathrm{m}^{-2}$ or $160 \mathrm{~g}$ biomass $\mathrm{m}^{-2}$, respectively). All individuals of $A$. caliginosa were 
Table 1 Plant species composition (\# of planted individuals in the community) of mesocosms with low ( $3 \mathrm{spp}$.) and high (12 spp.) plant diversity

\begin{tabular}{lcc}
\hline Functional type/species & $\begin{array}{c}\text { Number of individulas planted } \\
\text { per treatment }\end{array}$ \\
\cline { 2 - 3 } & Low diversity & High diversity \\
\hline Grasses & 20 & 5 \\
Arrhenatherum elatius L. & 0 & 5 \\
Bromus erectus Huds. & 0 & 5 \\
Festuca ovina L & 0 & 5 \\
Holcus lanatus L. & 0 & 5 \\
Forbs & 0 & 5 \\
Knautia arvensis L. & 20 & 5 \\
Leucanthemum ircutianum Mill. & 0 & 5 \\
Prunella vulgaris L. & 0 & 5 \\
Salvia pratensis L. & 0 & 5 \\
Legumes & 0 & 5 \\
Anthyllis vulneraria L & 0 & 5 \\
Lotus corniculatus L & 0 & 5 \\
Trifolium pratense L. & 0 & 5 \\
Vicia cracca L. & & 5 \\
\hline
\end{tabular}

collected by hand digging in a garden soil near the city of Wiener Neustadt (Lower Austria), while L. terrestris was obtained from a fishing bait shop in Vienna. Mesocosms were lined with plastic fleece at the bottom to prevent earthworms from escaping and then filled with a 40:60\% $\mathrm{vol} / \mathrm{vol}$ field soil:quartz sand substrate mixture $\left(\mathrm{pH}-\mathrm{H}_{2} \mathrm{O}=\right.$ $7.4, C_{\text {org }}=24.2 \mathrm{~g} \mathrm{~kg}^{-1}, \mathrm{~N}_{\text {tot }}=0.89 \mathrm{~g} \mathrm{~kg}^{-1}, \mathrm{P}-\mathrm{CAL}=61.1 \mathrm{mg}$ $\mathrm{kg}^{-1}$, K-CAL $\left.=107.6 \mathrm{mg} \mathrm{kg}^{-1}\right)$. The field soil was a Haplic Chernozem (silty loam) obtained from the BOKU Experimental Farm in Groß-Enzersdorf, near Vienna. This substrate mixture was successfully used in previous studies involving the same earthworm and/or plant species [43,44].

Each treatment was replicated six times. The experiment ran for 12 weeks from April until June 2010. Mean daily air temperature and mean relative humidity in the greenhouse during the experiment was $22.3 \pm 0.1^{\circ} \mathrm{C}$ and $61.3 \pm 0.3 \%$, respectively.

Five weeks after adding the earthworms we introduced two sub-adult, $5 \mathrm{~cm}$ long specimens of the invasive slug $A$. vulgaris into the specific mesocosms $\left(3.81 \mathrm{~g}\right.$ mesocosm $^{-1}$ total slug fresh mass); slugs were collected in the same garden as A. caliginosa. Prior to introduction into the mesocosms, slugs were kept in plastic boxes containing field soil in a climate chamber for about one week $\left(10^{\circ} \mathrm{C}\right.$, darkness for 24 hours) and given green lettuce ad libitum. Feeding with lettuce stopped one day before introducing them into the pots.

To prevent earthworms and/or slugs from escaping out of the pots a $50 \mathrm{~cm}$ high transparent plastic film smeared with soft soap at the upper rim was wrapped around each mesocosm. This plastic barrier was also attached to control treatments to provide similar microclimatic conditions across treatments.

\section{Harvesting procedure and measurements}

Earthworm activity was monitored once a week by observing surface casts, burrows or other relevant signs of their activity.

Slug herbivory was measured three times during the course of the experiment. First, three days after slug introduction we counted all leaves growing in the herbivory mesocosms with clear signs of slug damage (lesions). Second, we assessed slug herbivory when harvesting the plants by counting the number of leaves per plant species with slug damage. Third, we measured the leaf area eaten by slugs on scanned leaves of all species (flatbed scanner, 300 dpi resolution) using the freely available image analysis software ImageJ (http://rsbweb.nih.gov/ij/). These measures of slug herbivory were analysed for the three plant species that were present in both plant communities (the forb $P$. vulgaris, the legume $T$. pratense and the grass A. elatius.) as well as for the additional species. Seven days after introducing the slugs, they were removed, counted, weighed. Harvesting started by cutting individual plant specimens at the soil surface, measuring maximum plant length and counting number of tillers on three individuals of the grass $A$. elatius, the forb $P$. vulgaris and the legume $T$. pratense mesocosm ${ }^{-1}$. All plant material was dried at $55^{\circ} \mathrm{C}$ for 48 hours and weighed to assess dry matter production. One individual of the dried focus plant was ground in a ball mill and their $\mathrm{C}$ and $\mathrm{N}$ concentrations analysed using elementary analysis (LECO2000, St. Joseph, Michigan, USA).

Belowground biomass was harvested by flipping over the mesocosms and sorting out all roots and earthworms for a period of seven minutes mesocosm ${ }^{-1}$. Earthworms were counted and their fresh masses weighed after rinsing them under tap water and drying them on a paper towel. Roots were washed free of attached soil under a jet of tap water, dried at $55^{\circ} \mathrm{C}$ for at least three days and weighed.

\section{Statistical analyses}

We tested all variables for homogeneity of variances and normality using the tests after Levene and KolmogorovSmirnov, respectively [45]. Assumptions for parametric tests were fulfilled by all tested parameters. Treatment effects were first analysed using two-way ANOVAs with earthworms and plant community composition as fixed factors followed by Tukey post-hoc mean comparisons [45]. We used Pearson correlations to test the relationship between plant nutrient concentrations and slug damage. All statistical tests were performed using SPSS Statistics 
(vers. 17.0.0., SPSS Inc. Headquarters, Chicago, Illinois, USA). Values given throughout the text are means \pm standard error $(n=6)$.

\section{Results}

We observed earthworm activity throughout the course of the experiment in the form of surface casting, burrow openings or run-over toothpicks that marked plant seedlings (data not shown). At the harvest we found $62 \%$ of initially added number of earthworms weighing $42 \%$ of the initial earthworm biomass and 90\% of the introduced slug individuals weighing $85 \%$ of the initial biomass. Earthworm numbers (average between initially added and recovered individuals at harvest) were marginally affected by plant community composition with lower numbers when fewer plant species were present $\left(\mathrm{F}_{1,20}=3.270, \mathrm{P}=\right.$ 0.086 ) but not affected by slug herbivory. Earthworm biomass (average between initially added biomass and recovered biomass at harvest) was significantly affected by the composition of plant communities with lower biomass when fewer plant species were present $\left(\mathrm{F}_{1,20}=5.949, \mathrm{P}=\right.$ 0.024 ) but not affected by slug herbivory (data not shown).

Leaf length and number of tillers of $A$. elatius was unaffected by earthworms or the composition of plant communities (Table 2, Table 3). Leaf length and number of tillers of $P$. vulgaris was significantly higher in mesocosms containing more plant species but not affected by earthworms (Table 2, Table 3). Leaf length of $T$. pratense was significantly influenced by earthworms and plant community composition; number of tillers was significantly affected only by plant community composition (significant ew $\times$ plant composition interaction; Table 3 ).

Generally, earthworms directly affected $A$. elatius shoot mass (Table 3). However, plant community composition significantly increased total plant biomass, mainly due to an increased root mass at the cost of a significantly

\begin{tabular}{|c|c|c|c|c|}
\hline \multirow{2}{*}{$\begin{array}{l}\text { Parameter/ } \\
\text { Plant species }\end{array}$} & \multicolumn{2}{|c|}{ Low plant diversity } & \multicolumn{2}{|c|}{ High plant diversity } \\
\hline & $-E w$ & $+\mathrm{Ew}$ & $-E w$ & $+\mathrm{Ew}$ \\
\hline \multicolumn{5}{|c|}{ Maximum leaf length } \\
\hline A. elatius & $54.1 \pm 4.1 \mathrm{a}$ & $54.5 \pm 2.6 a$ & $59.9 \pm 1.3 a$ & $57.8 \pm 2.3 a$ \\
\hline P. vulgaris & $6.4 \pm 0.7 b$ & $5.7 \pm 0.6 b$ & $7.5 \pm 0.5 a$ & $8.5 \pm 0.4 a$ \\
\hline T. pratense & $23.6 \pm 1.3 c$ & $20.2 \pm 1.5 c$ & $30.4 \pm 1.2 \mathrm{a}$ & $27.4 \pm 1.0 b$ \\
\hline \multicolumn{5}{|c|}{ Number of tillers } \\
\hline A. elatius & $10.7 \pm 1.1 \mathrm{a}$ & $11.6 \pm 1.3 \mathrm{a}$ & $15.3 \pm 2.2 \mathrm{a}$ & $11.7 \pm 1.1 \mathrm{a}$ \\
\hline P. vulgaris & $6.1 \pm 0.9 b$ & $6.7 \pm 0.8 b$ & $9.6 \pm 1.4 a$ & $8.8 \pm 0.8 a$ \\
\hline T. pratense & $7.4 \pm 0.6 c$ & $6.1 \pm 0.4 b$ & $9.9 \pm 1.0 \mathrm{a}$ & $8.5 \pm 1.1 \mathrm{a}$ \\
\hline
\end{tabular}

Different letters after values refer to significant differences within a species (Tukey-Tests, $\mathrm{p}<0.05$ ). Means $\pm \mathrm{SE}, \mathrm{n}=6$. decreased shoot mass (Figure 1, Table 3). Response of shoot biomass production to plant community composition varied between plant functional groups with significantly decreased shoot mass in plant communities containing more plant species and significantly increased shoot mass of forbs (Figure 1, Table 3).

Neither earthworms nor plant community composition affected shoot total carbon concentration (Table 3, Table 4). Total plant $\mathrm{N}$ and $\mathrm{N}$ of focus species was significantly increased by earthworms; plant community composition had no effect on plant N (Table 3, Table 4). Consequently leaf $\mathrm{C}: \mathrm{N}$ ratios were significantly lower when earthworms were present but unaffected by plant community composition (Table 3 , Table 4).

Three days after slug introduction, significantly less leaves of $P$. vulgaris and $T$. pratense were damaged in plant communities containing twelve compared to three species; earthworms had no effect on slug damage after three days; overall herbivory after three days was unaffected by earthworms or plant community composition (Figure 2, Table 3). Six days after slug introduction, significantly less leaves and leaf area of $P$. vulgaris and $T$. pratense were consumed in plant communities containing twelve compared to three species; earthworms significantly reduced number of damaged leaves only in low diversity mesocosms and had no effect in high diversity mesocosms (Figure 2). Total number of damaged leaves was significantly lower in +Ew treatments but unaffected by plant community composition. Percent leaf area consumed (total species and focus species) was significantly lower in plant communities containing twelve species (Figure 2, Table 3). Earthworms increased eaten leaf area only for P. vulgaris and total plant community in communities containing only three plant species (Figure 2). Damage was not correlated to plant $\mathrm{C}, \mathrm{N}$ contents or C-to- $\mathrm{N}$ ratio (data not shown).

\section{Discussion}

Our results demonstrate that herbivory by the most important invasive slug species in Europe is influenced by earthworms, and that this influence varies with the species composition of plant communities. Although, plant communities with different numbers of plant species were similarly attacked by slugs (measured as number of damaged leaves), slugs consumed significantly less leaf area in plant communities containing twelve compared to three species. Leaf consumption of slugs was increased by earthworms in plant communities with fewer plant species but unaffected by earthworms in communities with more plant species. In the literature, results on effects of plant diversity on herbivory are heterogeneous ranging from no effect in herbivore damage of individual plants across a gradient of one to 60 plant species [46] to a decreased herbivory with increasing plant species richness [47]. For the 
Table 3 ANOVA results for the effects of earthworms and plant community composition on plant growth, plant quality and slug herbivory

\begin{tabular}{|c|c|c|c|c|c|c|}
\hline \multirow[b]{2}{*}{ Variable } & \multicolumn{2}{|c|}{ Earthworms } & \multicolumn{2}{|c|}{ Plant community comp. } & \multicolumn{2}{|c|}{ Ew x Pl.cc. } \\
\hline & $\mathrm{F}$ & $\mathbf{P}$ & $\mathbf{F}$ & $\mathbf{P}$ & $\mathbf{F}$ & $\mathbf{P}$ \\
\hline \multicolumn{7}{|l|}{ Plant growth } \\
\hline Focus spp. leaf length $(\mathrm{cm})$ & 0.030 & 0.863 & 2.307 & 0.130 & 0.056 & 0.813 \\
\hline A. elatius & 0.092 & 0.763 & 2.819 & 0.098 & 0.208 & 0.650 \\
\hline P. vulgaris & 0.048 & 0.828 & 12.106 & 0.001 & 2.438 & 0.124 \\
\hline T. pratense & 6.181 & 0.016 & 28.918 & $<0.001$ & 0.028 & 0.866 \\
\hline Focus spp. tiller numbers (funct. gr. ${ }^{-1}$ ) & 1.425 & 0.234 & 12.396 & 0.001 & 1.643 & 0.201 \\
\hline A. elatius & 0.815 & 0.370 & 2.481 & 0.120 & 2.364 & 0.129 \\
\hline P. vulgaris & 0.014 & 0.906 & 7.704 & 0.007 & 0.507 & 0.479 \\
\hline T. pratense & 2.700 & 0.105 & 9.094 & 0.004 & 0.001 & 0.003 \\
\hline Focus plants shoot biomass & 1.119 & 0.290 & 4.012 & 0.045 & 2.200 & 0.138 \\
\hline A. elatius shoot mass & 4.624 & 0.032 & 6.184 & 0.013 & 4.948 & 0.027 \\
\hline P. vulgaris shoot mass & 0.629 & 0.428 & 0.187 & 0.665 & 0.163 & 0.687 \\
\hline T. pratense shoot mass & 0.009 & 0.926 & 9.457 & 0.002 & 0.006 & 0.936 \\
\hline Total plant biomass (g mesoc..$^{-1}$ ) & 3.375 & 0.073 & 11.332 & 0.002 & 5.246 & 0.027 \\
\hline Total shoot biomass & 2.511 & 0.120 & 10.986 & 0.002 & 5.751 & 0.021 \\
\hline Total root biomass & 2.770 & 0.103 & 4.934 & 0.032 & 1.281 & 0.264 \\
\hline Total grass shoots & 0.344 & 0.560 & 36.226 & $<0.001$ & 2.302 & 0.136 \\
\hline Total forb shoots & 2.744 & 0.105 & 133.920 & $<0.001$ & 5.040 & 0.033 \\
\hline Total legume shoots & 0.891 & 0.350 & 0.115 & 0.736 & 0.304 & 0.584 \\
\hline \multicolumn{7}{|l|}{ Plant quality } \\
\hline Total plant $C_{\text {tot }}(\%)$ & 0.096 & 0.758 & 0.114 & 0.736 & 0.004 & 0.949 \\
\hline A. elatius $C_{\text {tot }}$ & 3.229 & 0.080 & 1.800 & 0.187 & 0.003 & 0.955 \\
\hline P. vulgaris $C_{\text {tot }}$ & 0.001 & 0.988 & 0.018 & 0.893 & 0.010 & 0.922 \\
\hline T. pratense $C_{\text {tot }}$ & 1.467 & 0.232 & 0.073 & 0.789 & 1.416 & 0.240 \\
\hline Total plant $\mathrm{N}_{\text {tot }}(\%)$ & 7.022 & 0.009 & 0.215 & 0.643 & 0.159 & 0.691 \\
\hline A. elatius $\mathrm{N}_{\text {tot }}$ & 5.728 & 0.021 & 0.127 & 0.723 & 0.056 & 0.814 \\
\hline P. vulgaris $\mathrm{N}_{\text {tot }}$ & 5.855 & 0.017 & 2.070 & 0.160 & 0.098 & 0.756 \\
\hline T. pratense $\mathrm{N}_{\text {tot }}$ & 5.604 & 0.022 & 0.121 & 0.730 & 3.394 & 0.072 \\
\hline Total plant C:N ratio & 6.324 & 0.013 & 0.232 & 0.631 & 0.045 & 0.833 \\
\hline A. elatius C:N ratio & 5.560 & 0.023 & 0.001 & 0.985 & 0.095 & 0.756 \\
\hline P. vulgaris C:N ratio & 0.360 & 0.553 & 1.484 & 0.232 & 0.073 & 0.789 \\
\hline T. pratense C:N ratio & 5.078 & 0.029 & 0.001 & 0.992 & 2.561 & 0.117 \\
\hline \multicolumn{7}{|l|}{ Slug herbivory } \\
\hline No. damaged leaves after 3 days & 0.406 & 0.531 & 2.075 & 0.165 & 0.002 & 0.965 \\
\hline P. vulgaris leaves damaged & 0.006 & 0.939 & 4.531 & 0.041 & 0.028 & 0.869 \\
\hline T. pratense leaves damaged & 0.138 & 0.714 & 5.248 & 0.033 & 0.138 & 0.714 \\
\hline No. damaged leaves after 6 days & 7.667 & 0.012 & 0.754 & 0.395 & 0.087 & 0.771 \\
\hline P. vulgaris leaves damaged & 2.621 & 0.121 & 11.346 & 0.003 & 1.555 & 0.227 \\
\hline T. pratense leaves damaged & 4.961 & 0.038 & 24.719 & $<0.001$ & 4.613 & 0.044 \\
\hline Total leaf area eaten mesocosm ${ }^{-1}$ & 0.754 & 0.387 & 10.371 & 0.002 & 3.432 & 0.066 \\
\hline P. vulgaris leaf area eaten & 0.374 & 0.543 & 5.500 & 0.023 & 1.750 & 0.191 \\
\hline T. pratense leaf area eaten & 0.606 & 0.440 & 6.803 & 0.012 & 0.010 & 0.922 \\
\hline
\end{tabular}


current study it is important to note that due to the design of the experiment we cannot distinguish between the effects of species diversity per se and the effects of species composition of the compared plant communities [48].

\section{Earthworm effects on slug herbivory}

Our first hypothesis that earthworms would differentially affect the growth and nutrient content of plant species that will consequently also alter the food choice of slugs was partly confirmed. While earthworms did not affect leaf length and number of tillers of three focus species, they changed the structure of plant communities by further reducing total aboveground biomass production in plant communities containing more plant species that already showed less productivity than plant communities containing three species only. Thus, reduced slug herbivory in communities with more plant species could also be the consequence of a greater choice of food sources and a less denser plant community structure, although other studies investigating different slug and plant species showed little influence of different food quantity on slug herbivory $[49,50]$.
Our second hypothesis that effects of earthworms will vary with plant community composition as communities containing more species commonly show a more complete resource use and earthworm-induced nutrient benefits would be less effective was also partly confirmed. Our data also suggest that the significantly higher root mass in stands with more plant species might have stimulated earthworm activity $[18,51]$ and thus increased their impact on slug herbivory. Earthworms increased $\mathrm{N}$ content of the three focus plant species regardless of the number of plant species present in plant communities, indicating a better nutrient availability of these plant species due to earthworm activity. Less diverse stands with a denser vegetation (more aboveground biomass) probably also had a microclimate more favourable for slugs [52]. The finding that earthworms reduced slug attacks regardless of plant community composition suggests that earthworm-induced changes in the chemical defense ability of plants $[42,53]$ is independent of plant community composition, however the possible role of secondary metabolites and defensive compounds on slug herbivory remains to be further investigated. Explanations for the stimulated leaf consumption

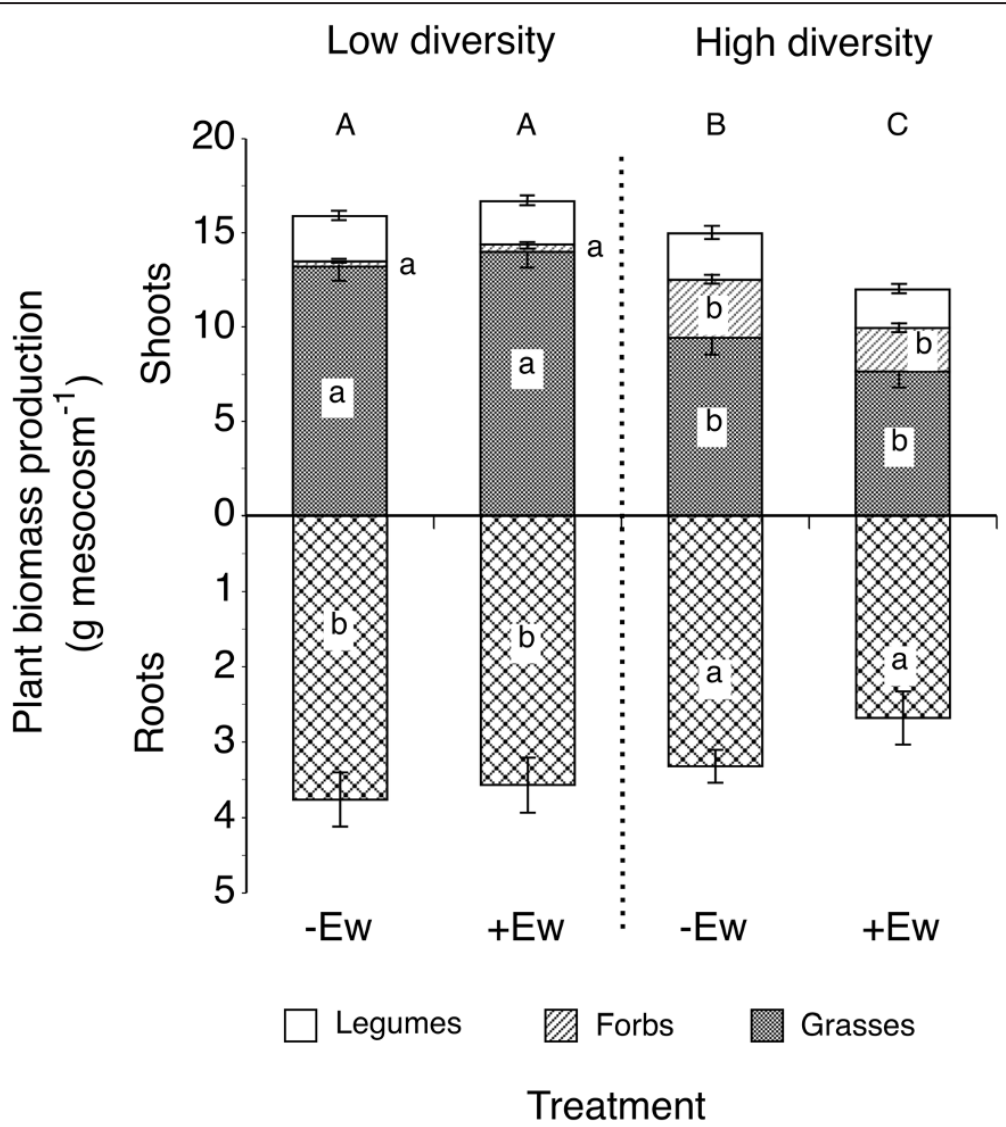

Figure 1 Biomass production of grasses, non-leguminous forbs and leguminous forbs in mesocosms planted with different community composition (low diversity - 3 spp.; high diversity - 12 spp.) without (-Ew) or with earthworms (+Ew). Only total roots are shown as they could not be assigned to certain functional groups. Different lower case letters denote significant differences among functional groups (Tukey, $\mathrm{P}<0.05)$; different capital letters denote differences of total shoot mass. Means $\pm S E, n=6$. 
Table 4 Leaf $\mathrm{C}, \mathrm{N}$ and $\mathrm{C}: \mathrm{N}$ ratios in response to earthworms (-Ew...no earthworms, +Ew...earthworm addition) and plant community composition (low diversity....3 spp.; high diversity...12 spp.)

\begin{tabular}{|c|c|c|c|c|}
\hline \multirow{2}{*}{$\begin{array}{l}\text { Parameter/ } \\
\text { Funct. group }\end{array}$} & \multicolumn{2}{|c|}{ Low plant diversity } & \multicolumn{2}{|c|}{ High plant diversity } \\
\hline & -Ew & $+\mathrm{Ew}$ & $-E w$ & $+E w$ \\
\hline \multicolumn{5}{|l|}{$C_{\text {tot }}$} \\
\hline A. elatius & $41.6 \pm 0.3 a$ & $40.5 \pm 0.4 a$ & $40.8 \pm 0.5 a$ & $39.7 \pm 1.0 a$ \\
\hline P. vulgaris & $38.4 \pm 1.0 \mathrm{a}$ & $38.5 \pm 0.5 a$ & $38.6 \pm 0.1 a$ & $38.5 \pm 0.8 a$ \\
\hline T. pratense & $40.9 \pm 0.3 a$ & $40.9 \pm 0.3 a$ & $40.6 \pm 0.3 a$ & $41.3 \pm 0.4 a$ \\
\hline \multicolumn{5}{|l|}{$N_{\text {tot }}$} \\
\hline A. elatius & $2.9 \pm 0.2 b$ & $3.5 \pm 0.3 a$ & $2.8 \pm 0.2 b$ & $3.4 \pm 0.3 a$ \\
\hline P. vulgaris & $2.7 \pm 0.1 b$ & $3.1 \pm 0.1 a$ & $2.9 \pm 0.1 b$ & $3.4 \pm 0.3 a$ \\
\hline T. pratense & $3.0 \pm 0.1 \mathrm{ab}$ & $3.1 \pm 0.2 \mathrm{ab}$ & $2.8 \pm 0.1 c$ & $3.3 \pm 0.1 a$ \\
\hline \multicolumn{5}{|l|}{ C:N ratio } \\
\hline A. elatius & $15.9 \pm 1.5 \mathrm{a}$ & $12.3 \pm 1.1 b$ & $15.3 \pm 1.2 \mathrm{a}$ & $12.7 \pm 1.3 b$ \\
\hline P. vulgaris & $14.3 \pm 0.7 a$ & $12.8 \pm 0.5 b$ & $13.9 \pm 0.6 a$ & $11.5 \pm 1.2 b$ \\
\hline T. pratense & $13.9 \pm 0.5 a$ & $13.5 \pm 0.4 a$ & $14.7 \pm 0.6 a$ & $12.7 \pm 0.5 b$ \\
\hline
\end{tabular}

Different letters after values refer to significant differences within a species (Tukey-Tests, $\mathrm{p}<0.05$ ). Means $\pm \mathrm{SE}, \mathrm{n}=6$.

in plant communities containing fewer species could be that (i) slugs were initially browsing (tasting) across available plant species causing lesions on leaves [54] and plants in mesocosms containing earthworms tasted less well or were better defended (e.g. by N-rich defense compounds), (ii) consumption in low diversity mesocosms was higher because more shoot mass was available known to influence slug herbivory [55].

Previous work has shown that earthworm biomass and activity is influenced by plant diversity $[18,19,21]$ and that earthworms themselves can influence plant diversity and growth $[22,26,56]$. The current results further indicate that the susceptibility of plant communities to herbivore attack is driven by a complex interaction between belowground detritivores, the community composition and productivity of grassland plant communities and the feeding behaviour of this generalist herbivore. Our results are in line with findings showing that earthworm impacts were of less importance in high diverse plant communities [11], likely due to high plant structural complexity. The former study also indicates that earthworms modulate the diversityinvasibility relationship and the stability of grassland plant communities. The current experimental setup precludes statements on invasibility in a strict sense as we added slugs, however, if we translate our findings to field conditions it could mean that managed grassland communities containing less plant species are more prone to herbivory by this invasive slug species and that earthworms may even increase this risk.

We observed a marked decline of earthworm numbers and biomass during the course of the experiment. Such declines are frequently observed in earthworm laboratory studies, especially when experiments lasted several months [26,57]. Based on our observation that earthworm activity changed little until the end of the experiment we assume that (i) the decline of earthworm numbers and weight loss occurred mainly within the last three days before harvest when we discontinued watering to facilitate the harvesting process, (ii) some worms might have been overlooked during the destructive harvest in the 201 mesocosms.

\section{Consequences for plant communities}

Slugs avoided the grass and preferred forbs and legumes in both plant communities which would lead towards more grassy communities in the long run. According to the current results, this process is expected to be enhanced as earthworms increase slug damage in communities containing less species. Although our plant communities were planted with same densities, plant functional group composition showed a shift towards significantly more grass and less forb biomass when only three plant species were present and a more balanced composition between functional groups when twelve plant species were present. This is also in line with the finding that earthworms increased leaf area consumed by slugs only at low diversity because especially the biomass production of the grass species was stimulated by earthworms $[12,22]$. Our third hypothesis that more plant species in a community will lead to reduced herbivory was confirmed. However, to what extent the decreased shoot biomass in these communities contributed to this feeding pattern demands further investigation.

Our results show a contradictory impact of earthworms on slug damage after three and six days of exposure. We assume that this depends merely on the fact that slugs became acquainted with different food sources [54]. It has been shown that earthworms influence the resistance of plant communities against plant invaders and this effect varied with plant diversity and with time $[11,20]$, possibly by altering the diversity-stability relationship. The current study shows that earthworms also affect herbivore invaders and that this effect varies with the composition of plant communities. So far only a few studies have confirmed the predicted decrease in herbivore damage in more diverse plant communities $[47,58,59]$.

Although planting densities were the same under both plant community compositions, more plant species in a community led to significantly more tillers and greater leaf lengths of model forb $P$. vulgaris and model legume T. pratense, whereas the model grass A. elatius remained unaffected by earthworms or plant community composition. We explain this by a greater competitive ability of these plants and a more complete resource use of these communities. In contrast to other studies earthworms 


\section{P. vulgaris}

T. pratense

Total herbivory

After 3 days of slug herbivory

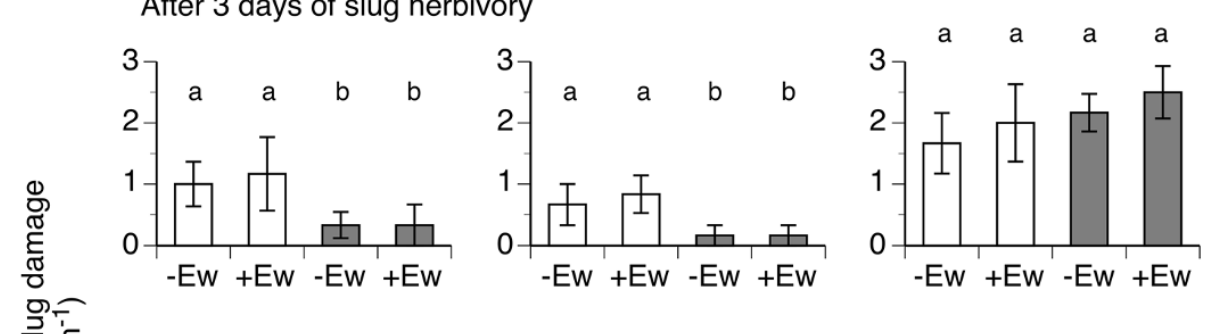

After 6 days of slug herbivory
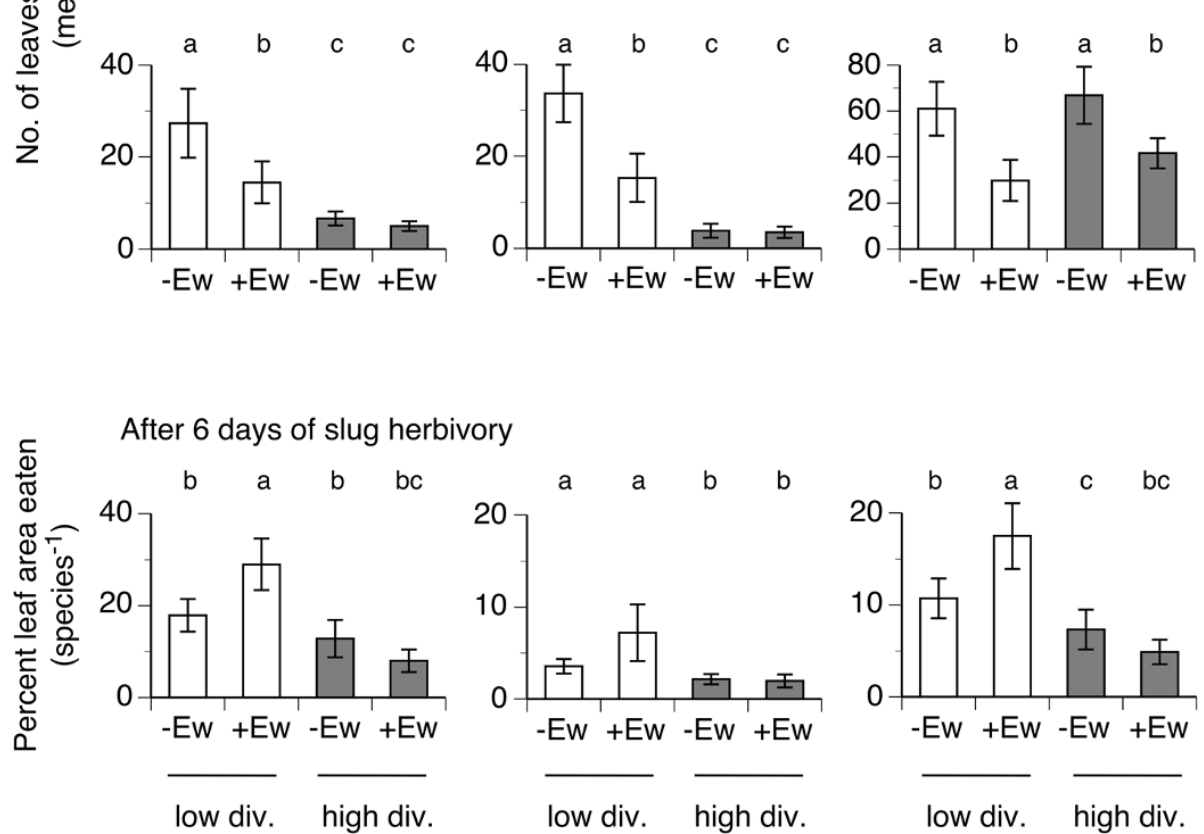

Figure 2 Slug herbivory on the forb $P$. vulgaris, the legume $T$. pratense and to total plant community measured three days (uppermost graphs) and six days after slug introduction (middle graphs and bottom graphs). Different letters denote significant differences among treatments within each plant species (Tukey, $P<0.05$ ). Means $\pm S E, n=6$.

did not promote biomass production of individual plant species [22,24], moreover at high diversity lower biomass was produced. The finding that low diversity stands have a higher biomass production than high diversity stands is well reflected in the literature [25] and can be attributed to niche-exploitation. There was a significant shift in biomass allocation from shoots to roots between plant communities containing three vs. twelve plant species suggesting a higher competition for available resources in communities containing more plant species. A similar pattern with reduced shoot biomass and $\mathrm{N}$ uptake in the presence of earthworms of the legume $T$. repens was reported earlier [24]. Earthworms have been shown to enhance the growth of grasses under short-term experimental conditions while legumes are more likely to respond only in the long-term $[22,27,60]$. But even if there was an increased $\mathrm{N}$ mineralization through earthworms it would mainly benefit grasses anyway [12]. The majority of studies showed growth stimulation by earthworms $[28,61]$, however many of these studies investigated single plants only, while earthworm effects conducted in plant communities frequently show little or no earthworm effect on biomass production [27].

\section{Conclusions}

Taken together, our results show that aboveground invasive generalist herbivores can be influenced by belowground detritivores and that this influence can depend on the composition of the plant community. Our results suggest that communities containing more plant species are less prone to be attacked by this slug herbivore; in plant communities containing less plant species earthworms 
can make leaves even more attractive for slugs. In order to fully understand plant species interactions and ecosystem functioning, these belowground-aboveground linkages $[62,63]$ need to be considered more widely.

\section{Competing interests}

All authors declare that they have no competing interests.

\section{Authors' contributions}

All authors contributed to data collection and/or analysis of project results. JGZ, TF and TD wrote the majority of the paper with contributions from the co-authors. All authors have read and approved the final manuscript.

\section{Acknowledgements}

We are grateful to Lisa Kargl, Lina Weissengruber, Raphaël Trouvé and Norbert Schuller for help in the greenhouse and laboratory. This research was supported by the Austrian Science Fund (FWF, project no. P20171-B16).

\section{Author details}

${ }^{1}$ Institute of Zoology, Department of Integrative Biology and Biodiversity Research, University of Natural Resources and Life Sciences Vienna, Gregor Mendel Straße 33, A-1180, Vienna, Austria. ${ }^{2}$ Research Institute of Organic Agriculture (FiBL Austria), A-1070, Vienna, Austria.

Received: 5 April 2013 Accepted: 23 April 2013

Published: 13 May 2013

\section{References}

1. United Nations Environment Programme: Millennium Ecosystem Assessment. In Encyclopedia of Earth. Edited by Cleveland CJ. Washington, DC, USA: Environmental Information Coalition, National Council for Science and the Environment; 2006

2. Schulze ED, Mooney HA: Biodiversity and ecosystem functioning. Berlin, Germany: Springer-Verlag; 1994.

3. Loreau M, Naeem S, Inchausti P: Biodiversity and ecosystem functioning - Synthesis and Perspectives. New York, USA: Oxford University Press; 2002.

4. Fargione JE, Tilman D: Diversity decreases invasion via both sampling and complementarity effects. Ecol Lett 2005, 8:604-611.

5. Elton CS: The ecology of invasions by animals and plants. London, UK: Methuen; 1958.

6. Levine $J M$, D'Antonio CM: Elton revisited: a review of evidence linking diversity and invasibility. Oikos 1999, 87:15-26.

7. Dukes JS, Mooney HA: Does global change increase the success of biological invaders? TREE 1999, 14:135-139.

8. Hooper DU, Chapin FS, Ewel JJ, Hector A, Inchausti P, Lavorel S, Lawton JH, Lodge DM, Loreau M, Naeem S, et al: Effects of biodiversity on ecosystem functioning: A consensus of current knowledge. Ecol Monogr 2005, 75:3-35.

9. Wardle DA, Bardgett RD, Callaway RM, Van der Putten WH: Terrestrial Ecosystem Responses to Species Gains and Losses. Science 2011, 332:1273-1277.

10. Dukes JS: Species composition and diversity affect grassland suceptibility and response to invasion. Ecologial Applications 2002, 12:602-617.

11. Eisenhauer N, Milcu A, Allan E, Nitschke N, Scherber C, Temperton V, Weigelt A, Weisser WW, Scheu S: Impact of above- and below-ground invertebrates on temporal and spatial stability of grassland of different diversity. J Ecol 2011, 99:572-582.

12. Eisenhauer N, Scheu S: Invasibility of experimental grassland communities: the role of earthworms, plant functional group identity and seed size. Oikos 2008, 117:1026-1036.

13. Lavelle P: Earthworm activities and the soil system. Biol Fertil Soils 1988, 6:237-251.

14. Wolters V, Joergensen RG: Microbial carbon turnover in beech forest soils worked by Aporrectodea caliginosa (Savigny) (Oligochaeta: Lumbricidae). Soil Biol Biochem 1992, 24:171-177.

15. Bohlen PJ, Edwards CA: Earthworm effects of $\mathrm{N}$ dynamics and soil respiration in microcosms receiving organic and inorganic nutrients. Soil Biol Biochem 1995, 27:341-348.

16. Edwards CA, Bohlen PJ: Biology and ecology of earthworms. 3rd edition. London: Chapman \& Hall; 1996.
17. Bouché MB: Strategies lombriciennes. In Soil Organisms as Components of Ecosystems. Edited by Lohm U, Persson T. Stockholm: Volume Ecological Bulletins 25; 1977:122-133.

18. Zaller JG, Arnone JA: Earthworm responses to plant species' loss and elevated $\mathrm{CO}_{2}$ in calcareous grassland. Plant Soil 1999, 208:1-8.

19. Spehn EM, Joshi J, Schmid B, Alphei J, Körner C: Plant diversity effects on soil heterotrophic activity in experimental grassland ecosystems. Plant Soil 2000, 224:217-230.

20. Eisenhauer N, Milcu A, Sabais ACW, Scheu S: Animal ecosystem engineers modulate the diversity-invasibility relationship. PLoS One 2008, 3:e3489.

21. Arnone JA, Zaller JG, Hofer G, Schmid B, Körner C: Loss of plant biodiversity eliminates stimulatory effect of elevated $\mathrm{CO}_{2}$ on earthworm casting activity in grasslands. Oecologia 2013, 171:613-622.

22. Zaller JG, Arnone JA: Interactions between plant species and earthworm casts in a calcareous grassland under elevated $\mathrm{CO}_{2}$. Ecology 1999, 80:873-881.

23. Kreuzer K, Bonkowski M, Langel R, Scheu S: Decomposer animals (Lumbricidae, Collembola) and organic matter distribution affect the performance of Lolium perenne (Poaceae) and Trifolium repens (Fabaceae). Soil Biol Biochem 2004, 36:2005-2011.

24. Wurst S, Langel R, Scheu S: Do endogeic earthworms change plant competition? A microcosm study. Plant Soil 2005, 271:123-130.

25. Eisenhauer N, Milcu A, Nitschke N, Sabais A, Scherber C, Scheu S: Earthworm and belowground competition effects on plant productivity in a plant diversity gradient. Oecologia 2009, 161:291-301.

26. Zaller JG, Heigl F, Grabmaier A, Lichtenegger C, Piller K, Allabashi R, Frank T, Drapela T: Earthworm-mycorrhiza interactions can affect the diversity, structure and functioning of establishing model grassland communities. PLoS One 2011, 6:e29293.

27. Zaller JG, Arnone JA: Earthworm and soil moisture effects on the productivity and structure of grassland communities. Soil Biol Biochem 1999, 31:517-523.

28. Scheu S: Effects of earthworms on plant growth: patterns and perspectives. Pedobiol 2003, 47:846-856.

29. Brown GG, Edwards CA, Brussaard L: How earthworms affect plant growth: burrowing into the mechanisms. In Earthworm Ecology. 2nd edition. Edited by Edwards CA. Boca Raton, FL, USA: CRC Press; 2004:13-49.

30. Eisenhauer N, Sabais ACW, Schonert F, Scheu S: Soil arthropods beneficially rather than detrimentally impact plant performance in experimental grassland systems of different diversity. Soil Biol Biochem 2010, 42:1418-1424

31. Eisenhauer N, Schädler M: Inconsistent impacts of decomposer diversity on the stability of aboveground and belowground ecosystem functions. Decologia 2011, 165:403-415.

32. Silva O, Teresa M: Effects of mollusc grazing on the development of grassland species. J Veg Sci 1992, 3:267-270

33. Thompson L, Thomas CD, Radley JMA, Williamson S, Lawton JH: The effect of earthworms and snails in a simple plant community. Oecologia 1993, 95:171-178.

34. Hanley ME, Fenner M, Edwards PJ: An experimental study of the effects of mollusc grazing on seedling recruitment and survival in grassland. J Ecol 1995, 83:621-627.

35. Frank T: Influence of slug herbivory on the vegetation development in an experimental wildflower strip. Basic Appl Ecol 2003, 4:139-147.

36. Zaller JG, Searles PS, Rousseaux MC, Flint SD, Caldwell MM, Sala O, Ballaré CL, Scopel AL: Solar ultraviolet-B radiation can affect slug feeding preference for some plant species native to a fen ecosystem in Tierra del Fuego, Argentina. Plant Ecol 2003, 169:43-51.

37. Buschmann H, Keller M, Porret N, Dietz H, Edwards PJ: The effect of slug grazing on vegetation development and plant species diversity in an experimental grassland. Funct Ecol 2005, 19:291-298.

38. Peters HA: The significance of small herbivores in structuring annual grassland. J Veg Sci 2007, 18:175-182.

39. Cottam DA: The effects of slug-grazing on Trifolium repens and Dactylis glomerata in monoculture and mixed swards. Oikos 1986, 47:275-279.

40. Cowie RH, Dillon RT, Robinson DG, Smith JW: Alien non-marine snails and slugs of priority quarantine importance in the United States: A preliminary risk assessment. Am Malacol Bull 2009, 27:113-132.

41. Coeurdassier M, Scheifler R, de Vaufleury A, Crini N, Saccomani C, Du Mont LS, Badot PM: Earthworms influence metal transfer from soil to snails. Appl Soil Ecol 2007, 35:302-310. 
42. Wurst S: Effects of earthworms on above- and belowground herbivores. Appl Soil Ecol 2010, 45:123-130.

43. Putz B, Drapela T, Wanek W, Schmidt O, Frank T, Zaller JG: A simple method for in-situ-labelling with ${ }^{15} \mathrm{~N}$ and ${ }^{13} \mathrm{C}$ of grassland plant species by foliar brushing. Methods Ecol Evol 2011, 2:326-332.

44. Zaller JG, Frank T, Drapela T: Soil sand content can alter effects of different taxa of mycorrhizal fungi on plant biomass production of grassland species. Europ J Soil Biol 2011, 47:175-181.

45. Zar JH: Biostatistical Analysis. 4th edition. Englewood Cliffs, NJ, USA: Prentice-Hall; 1998

46. Scherber C, Mwangi PN, Temperton VM, Roscher C, Schumacher J, Schmid $B$, Weisser WW: Effects of plant diversity on invertebrate herbivory in experimental grassland. Oecologia 2006, 147:489-500.

47. Unsicker SB, Baer N, Kahmen A, Wagner M, Buchmann N, Weisser WW: Invertebrate herbivory along a gradient of plant species diversity in extensively managed grasslands. Oecologia 2006, 108:643-647.

48. Hooper DU, Vitousek PM: The effects of plant composition and diversity on ecosystem processes. Science 1997, 277:1302-1305.

49. Cook R, Bailey S, McCrohan C: Slug preferences for winter wheat cultivars and common agricultural weeds. J Appl Ecol 1996, 33:866-872.

50. Raut S, Panigrahi A: Feeding rhythm in the garden slug Laevicaulis alte (Soleolifera: Veronicellidae). Malacol Rev 1990, 23:39-46.

51. Zaller JG, Arnone JA: Activity of surface-casting earthworms in a calcareous grassland under elevated atmospheric $\mathrm{CO}_{2}$. Oecologia 1997, 111:249-254.

52. Milcu A, Partsch S, Scherber C, Weisser WW, Scheu S: Earthworms and legumes control litter decomposition in a plant diversity gradient. Ecology 2008, 89:1872-1882.

53. Wurst S, Dugass-Gobena D, Scheu S: Earthworms and litter distribution affect plant defensive chemistry. J Chem Ecol 2004, 30:691-702.

54. South A: Terrestrial Slugs. Biology, Ecology, Control. London: Chapman \& Hall; 1992.

55. Peters HA, Baur B, Bazzaz F, Körner C: Consumption rates and food preferences of slugs in a calcareous grassland under current and future CO2 conditions. Oecologia 2000, 125:72-81.

56. Zaller JG, Saxler N: Selective vertical seed transport by earthworms: implications for the diversity of grassland ecosystems. Europ J Soil Biol 2007, 43:S86-591.

57. Wurst S, Dugassa-Gobena D, Langel R, Bonkowski M, Scheu S: Combined effects of earthworms and vesicular-arbuscular mycorrhizas on plant and aphid performance. New Phytol 2004, 163:169-176.

58. Mulder CPH, Koricheva J, HussDanell K, Hogberg P, Joshi J: Insects affect relationships between plant species richness and ecosystem processes. Ecol Lett 1999, 2:237-246.

59. Jactel H, Brockerhoff EG: Tree diversity reduces herbivory by forest insects. Ecol Lett 2007, 10:835-848.

60. Laossi KR, Noguera DC, Bartolomé-Lasa A, Mathieu J, Blouin M, Barot S: Effects of endogeic and anecic earthworms on the competition between annual plants and their relative fecundity. Soil Biol Biochem 2009. 41:1668-1673.

61. Eisenhauer N, Scheu S: Earthworms as drivers of the competition between grasses and legumes. Soil Biol Biochem 2008, 40:2650-2659.

62. Bardgett RD, Wardle DA: Aboveground-belowground linkages. Biotic interactions, ecosystem processes, and global change. Oxford, UK: Oxford University Press; 2010.

63. Eisenhauer N: Aboveground-belowground interactions as a source of complementarity effects in biodiversity experiments. Plant Soil 2012, 351:1-22.

doi:10.1186/1472-6785-13-20

Cite this article as: Zaller et al:: Herbivory of an invasive slug is affected by earthworms and the composition of plant communities. BMC Ecology 2013 13:20.

\section{Submit your next manuscript to BioMed Central and take full advantage of:}

- Convenient online submission

- Thorough peer review

- No space constraints or color figure charges

- Immediate publication on acceptance

- Inclusion in PubMed, CAS, Scopus and Google Scholar

- Research which is freely available for redistribution

Submit your manuscript at www.biomedcentral.com/submit
C Biomed Central 